help of the British national appeal of the World Wildlife

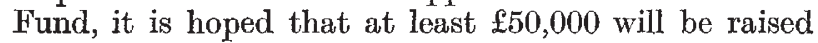
to cover the purchase, to maintain the island as a nature reserve and set up a permanent research study centre.

The Scychelles are important because of the large numbers of endemic land birds they support; the fact that the Seychelles are an archipelago has probably had something to do with this. In the early eighteenth century, when the islands were first colonized, there were about a dozen endemic species on most of them. As the human settlements became larger and the islands more cultivated, the birds became rarer. Last century, at least three and possibly four of the species bccame extinct, and today the remaining endemic species are to be found on only one or two of the islands. The felling of trees and the introduction of rodents and cats by man are thought to have led to the disappearance and restriction in range of these birds.

Cousin Island is still fairly well stocked with endemics and from all accounts it would be ideal as a sanctuary and as a centre for studying the whole archipelago. Unfortunately, pigs are being allowed to run wild in the scrub of the north-eastern plateau with disastrous results for the bird population. It is becoming more urgent than ever, therefore, to buy the island for conservation, so that control can be kept over the vegetation and the introduced animals.

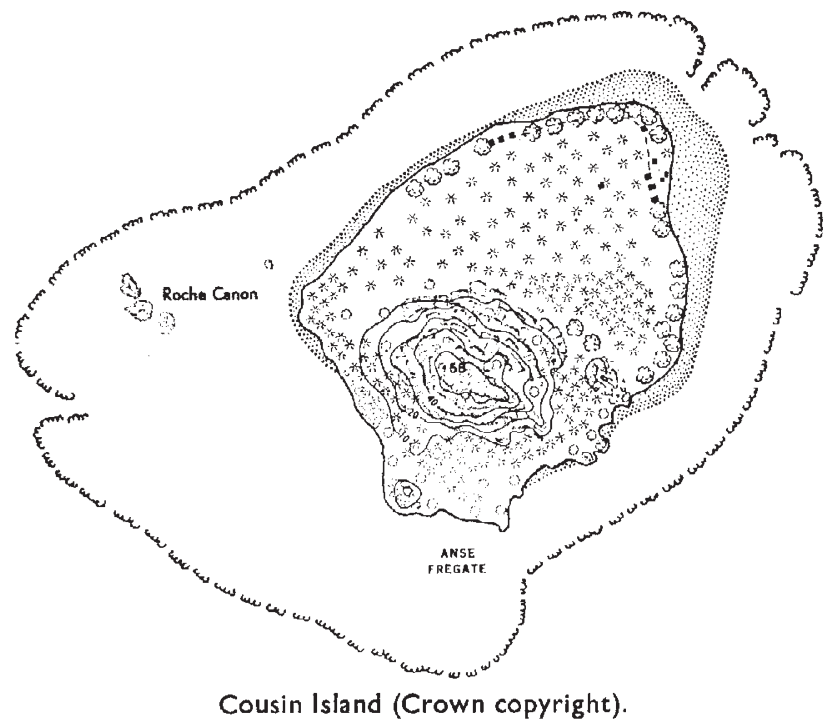

It seems to be agreed that Cousin is particularly important because it is the only remaining home of the brush warbler (Nesillas (Bebrornis) sechellanis), of which only 50 are left. The bird breeds in dense cover, especially over the marshy area in the southwest of the island. The turtle dove, streptopelia picturata rostrata, is also unique to Cousin. This endemic subspecies has been swamped in the other islands by interbreeding with an introduced form, S.p. picturata, from Madagascar. On Cousin, however, the endemic characters are retained to a great extent. The island is also one of the three remaining places where the Seychclles fody or toq toq (Foudia sechellarum) is found, and it also the only breeding place in the Indian Ocean of the rare lesser noddy (Anous $t$. tenuirostris), which otherwise breeds only on a small group off Western Australia. Apart from these rare birds, there are large colonies of the fairy tern (Anous alba monte), shearwaters and nesting tropicbirds (Phaethon $l$, lepturus).

There are also some giant tortoises introduced to the island by a previous owner. These are a different shape from those on Aldabra. Unfortunately the young were removed a long time ago as pets so that today only six adults remain. Apparently each tortoise has to be bought individually along with the island: it is anyone's guess how much each will fetch.

\section{New Units for Nature}

In accordance with the advice of the Royal Society Conference of Editors that scientific journals should adopt the SI system of units (Nature, 216, 1272; 1967), Nature will be using the recommended symbols. This means that some of our abbreviations will be changed, as shown in the table. This will apply to all communications now accepted for publication.

Symbols previously
used in Nature
sec
amp
candela
steradian
coulomb
farad
lumen
lux
cycles/sec
parsec
c. (curie)

Symbols to be
adopted
s
$\mathrm{A}$
$\mathrm{cd}$
$\mathrm{sr}$
$\mathrm{C}$
$\mathrm{F}$
$\mathrm{Im}$
$\mathrm{lx}$
$\mathrm{Hz}$
$\mathrm{pc}$
$\mathrm{Ci}$

In the article referred to above, giga was shown as $10^{6}$ and not $10^{9}$. One atmosphere should be $1 \cdot 01325 \mathrm{~N} \mathrm{~m}^{-2}$.

\section{Parliament in Britain}

\section{Forestry}

Mr HAY, joint Parliamentary Secretary at the Ministry of Agriculture, Fisheries and Food, gave the acres planted by the Forestry Commission in England, Scotland and Wales in each of the ten years 19581967. In 1967 , of the 52,500 acres planted, 11,200 were in England, 34,500 in Scotland and 6,800 in Wales. Now planting in Scotland was planned to increase to 50,000 acres a year by 1976 . The planting programmes for England and Wales were under review. (Written answer, January 17.)

\section{School Leavers}

THE Secretary of State for Education and Science, Mr P. Gordon Walker, stated that of school leavers in $1965-66,5 \cdot 5$ per cent went into universities, $3 \cdot 1$ per cent to colleges of education, $1 \cdot 1$ per cent to full-time (and sandwich) degree and $\mathrm{HND} / \mathrm{HNC}$ courses in further education establishments and 8.1 per cent to other full-time and sandwich courses at further education establishments, most of the latter courses being non-advanced. Between 50 and 55 per cent of boys and girls were expected to remain at school voluntarily in 1969-70 for a full year beyond the minimum statutory school-leaving age. (Written answer, January 17.) 